\title{
Assessing the Detoxication Efficiencies of Wastewater Treatment Processes Using a Battery of Bioassays/Biomarkers
}

\author{
Mei Ma, Jian Li, Zijian Wang \\ State Key Laboratory of Environmental Aquatic Chemistry, Research Center for Eco-Environmental Sciences, Chinese Academy of Sciences, P. O. Box \\ 2871, Beijing, 100085, P. R. China
}

Received: 9 October 2004/Accepted: 1 June 2005

\begin{abstract}
A battery of in vitro bioassays, including a Neutral Red (NR) assay using MCF-7 cells for predicting cytotoxic chemicals, an ethoxy resorufin-O-deethylase (EROD) activity assay using H4IIE cells to check for dioxin-like chemicals, and a recombinant gene yeast assay for screening estrogenic chemicals, was conducted to assess the removal efficiencies of trace toxic chemicals by different treatment processes in the waste water treatment plant (WWTP). The effluents were extracted by solid phase extraction (SPE) and were fractionated into three fractions based on polarities. The battery of bioassays was performed for each fraction. In the battery, the toxicities of the effluents were described according to their modes of actions (MOA) or biomarkers and the properties of the toxic chemicals were categorized by their polarities and MOAs. The proposed procedure could be used as a tool to diagnose the toxic characteristics of the complicate mixture. The results showed that cytotoxic, dioxin-like and estrogenic chemicals could be detected in all samples. In the influent, cytotoxic and dioxin-like chemicals were mainly in polar fraction and estrogenic chemicals were in non-polar and moderate-polar fractions. The secondary treatment (active sludge) could remove a small amount of these toxicants. Among different types of advanced treatments, flocculation was good enough to remove most of the cytotoxic chemicals and a combination of flocculation, ozone oxidation, and post-biological treatment could eliminate most of the dioxin-like and estrogenic chemicals.
\end{abstract}

In recent years, with the development of industry and agriculture, many thousands of organic trace pollutants, such as polychlorinated biphenyls (PCBs), organochlorine pesticides (OCPs), polycyclic aromatic hydrocarbons (PAHs), polychlorinated dibenzofurans (PCDFs), and dibenzo- $p$-dioxins (PCDDs) have been produced. Most of these chemicals may pose a direct or potential hazard to the aquatic biota and public health. Wastewater treatment plants (WWTPs) effluents are relevant point resources for residues of these compounds in the

Correspondence to: Zijian Wang; email: wangzj@mail.rcees.ac.cn aquatic environment (Clara et al. 2005). The parameters such as biochemical oxygen demand (BOD), chemical oxygen demand (COD), total organic carbon (TOC), among others, are not feasible for the evaluation of the elimination efficiency of these groups of toxic pollutants. However, chemistry analysis, in conjunction with modern powerful chemical techniques such as gas chromatography-mass spectrometry (GC-MS), liquid chromatography-mass spectrometry (LC-MS), and liquid chromatography-nuclear magnetic resonance (LC-NMR), can detect increasing numbers of pollutants. But the instrumental analyses are expensive, and, in several cases, only a few percent of the organic pollutants can be identified (Betowski et al. 1996). It was thus considered that biological toxicity testing is a direct measure of the overall toxicity of the effluents, the intention of which is to compensate limitations arising for traditional analyses. It is for this reason that the whole effluent toxicity (WET) testing is being included by US-EPA in assessments of effluents (US-EPA 2002a).

WET testing is an integrative tool that measures the toxic effect of an effluent mixture as a whole and accounts for both uncharacterized sources of toxicity as well as toxic interactions. However, all the tests in WET are performed on a whole-organism level, where the acute or chronic effects on exposed aquatic organisms such as alga, daphnia magna, and fish are determined. Whole-organism-level tests are expensive, time- and labor-consuming, and require much laboratory space. There are great variations among the individual animal, which leads to problems with the standardization. Therefore, there is a need for a fast, reliable, reproducible, and inexpensive bioassay for the rapid screening of potential toxic pollutants in wastewater or effluents after treatment. Biomarkers based on in vitro bioassays offer a rapid, sensitive, and relatively inexpensive solution to some of the limitations of whole-organism-level tests. They enable estimation of the total biological activity of all compounds that act through the same mode of action present in extracts of any environmental media, and they also integrate possible interactions among chemicals (Giesy et al. 2002).

One of the most important toxic effects produced by toxic chemicals is the dioxin-like activity (Hilscherova et al. 2001). These chemicals bind to the arly hydrocarbon receptor (AhR) 


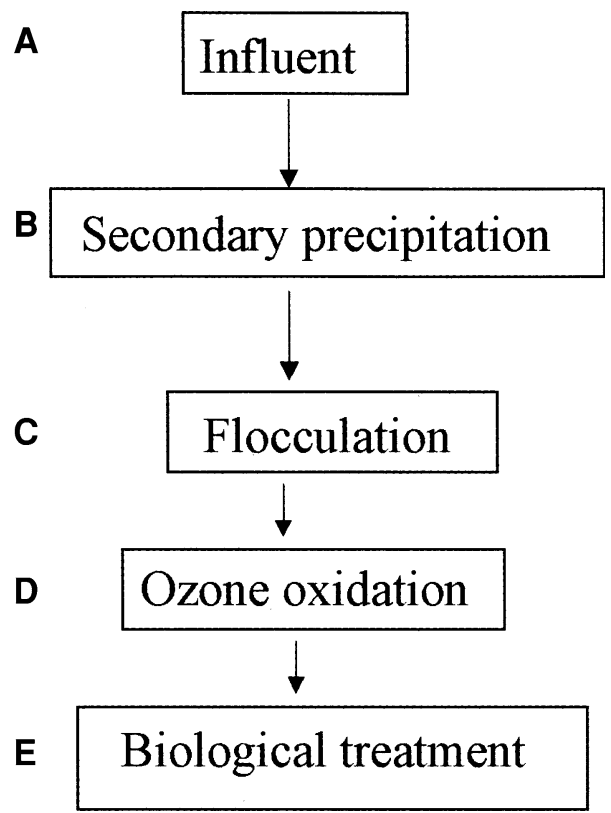

Fig. 1. Flow scheme of the advanced treatment processes and sampling locations

present in the cytosol. Their binding affinity is related to the incidence and intensity of toxic effects (Lucier et al. 1993, Hankinson 1995). Binding of a ligand to the AhR initiates a cascade of actions leading to enhanced transcription of AhRregulated genes and increases in activities of AhR responsive enzymes (Zacharewski et al. 1995). Ethoxy resorufin-O-deethylase (EROD) is a member of the AhR-responsive enzymes. Organic compounds known to bind to the AhR include PCBs, PAHs, chlorinated dibenzodioxinx, and chlorinated dibenzofurans (Hansen and Addisson 1990), which are often found together in environmental matrices. Extensive studies have suggested that H4IIE-cell EROD assay can be used to pinpoint the sources and identities of dioxin-like chemicals (Whyte et al. 2004).

Many recent studies have demonstrated that WWTP effluents affect the development of fish embryos and larvae (Tabata et al. 2001). Endocrine disruption activity in WWTP effluents has also been frequently studied (Nasu et al. 2001; Murk et al. 2002; Alatriste-Mondragon et al. 2003). This effect was attributed to a group of chemicals including natural products, pharmaceuticals, and industrial chemicals, which have been shown to be estrogen mimics. These substances have been associated with degenerative effects such as reduced fecundity, changes in the sex ratio, developmental degeneration in both animal and human embryos (Knörr and Braunbeck 2002), as well as an increase in breast and testis cancer in humans (Toppari et al., 1996). Numerous specific testing systems have been developed for the detection of the estrogenic effects (Routledge and Sumpter 1996; Sohoni and Soto 1998; Go et al. 1999). Among them, recently developed recombinant yeast screen (Routledge and Sumpter, 1996) can serve as a very useful tool to rapidly and inexpensively determine the total potency of estrogenic chemicals in the mixtures of chemicals. In this yeast strain, transactivation of a receptor gene (predominantly bacterial $\beta$-galactosidase) controlled by the respective hormone-responsive DNA elements served as proof for the functionality of the cloned protein (Routledge and Sumpter, 1996).

There are various assay methods for evaluating the cytotoxic effects of chemicals on cultured cells. The most common applications of cytotoxic testing techniques are based on cell viability. Among them, NR assay is a well-known quantitative colorimetric method (Borenfreund and Puerner, 1985). The assay is based on the uptake of neutral red dye, which accumulates in the lysosomes of uninjured cells.

Bioassay based on biomarker is promising due to its molecular and biological simplicity, easy handling, and low costs (Ramamoorthy et al. 1997). In addition, this assay is valuable because it is able to indicate a potential mechanism of action as well as to account for synergistic, antagonistic, and additive interactions that may occur with a complex mixture. The purpose of this report is to evaluate a battery of bioassays based on three representative biomarkers for toxicity evaluation of wastewater and effluents after treatment processes and for diagnosis of toxic characteristics of a complicated mixture.

\section{Materials and Methods}

\section{Sample Collection and Processing}

Wastewater and effluents samples were taken in May 2003 from a pilot plant in a Beijing WWTP. This pilot plant was constructed for reclamation of the wastewater after a combination of secondary and advanced treatment processes (Fig. 1). The samples include influent (A), effluent after secondary biological treatment (B), effluent from flocculation process $(C)$, effluent from ozone oxidation process (D), and effluent from a post-biological treatment (E). Composite water samples (2L) were taken over a period of $24 \mathrm{~h}$ according to the protocol (US EPA, 2002a) and were processed immediately upon arrival in the laboratory. Water samples were filtered through $0.7-\mu \mathrm{m}$ glass fiber filters (APFF, Millipore, Bedford, MA) and extracted by solid phase extraction (SPE) using Oasis HLB cartridges $(6 \mathrm{~mL}, 500 \mathrm{mg}$, Waters), which had been conditioned with $5 \mathrm{~mL} \mathrm{CH}_{2} \mathrm{Cl}_{2}$ (HPLC Grade, Fisher), $5 \mathrm{~mL}$ methanol (HPLC Grade, Fisher), as well as $5 \mathrm{~mL}$ deionised water. The columns were then eluted three times with $5 \mathrm{~mL}$ $\mathrm{CH}_{2} \mathrm{Cl}_{2}$ and elutes collected were combined. This is followed by blowing it to $1 \mathrm{~mL}$ under a nitrogen stream (Rao et al. 2005).

\section{Fractionation Based on Polarity}

The extract was carefully added on a column containing $10 \mathrm{~g}$ silica (60-200 $\mu \mathrm{m}, 60 \mathrm{~A}$, ultra pure, Acros Organics) and $10 \mathrm{~g} \mathrm{Al}_{2} \mathrm{O}_{3}(50-200$ Micron, Acros Organics) and then fractionated as described by $\mathrm{Wu}$ et al. (2002) with some modifications. Briefly, the column was eluted with $15 \mathrm{~mL}$ hexane (HPLC Grade, Fisher) to yield a non-polar fraction (F1), followed by $70 \mathrm{~mL}$ mixture of hexane/ $\mathrm{CH}_{2} \mathrm{Cl}_{2}$ (v/v=7:3, HPLC Grade, Fisher) to afford a fraction with moderate polarity (F2), and finally by methanol $(30 \mathrm{~mL}$, HPLC Grade, Fisher) to produce a polar fraction (F3). This separation was confirmed by using a spike recovery test and recoveries of target analytes were between $80 \%-105 \%$.

The sub-fractions were evaporated to $2 \mathrm{~mL}$ using a rotationevaporate, then blown to dryness with a gentle nitrogen flow. The residues were dissolved in $1 \mathrm{~mL}$ DMSO (ACS Grade, Amresco ${ }^{\circledR}$ ) and diluted by a 0.5 -fold dilution series. The DMSO solution $(5 \mu \mathrm{L})$ was added to $995 \mu \mathrm{L}$ culture medium and homogenized about $1 \mathrm{~min}$ in a 
vortex apparatus. Thereby, maximum solvent concentration in the culture medium did not exceed $0.5 \%$, a concentration that did not affect cell growth. Five concentration levels were chosen for doseresponse relationship test. To control the effects due to DMSO, the same amount of the organic solvent was added.

\section{Neutral Red Assay}

The NR assay was conducted according to the method described by Babich and Borenfreund (1987a). Briefly, individual wells of a 96well plate were inoculated with $0.2 \mathrm{~mL}$ complete medium containing $2 \times 10^{4} \mathrm{MCF}-7$ cells and incubated for $24 \mathrm{~h}$. The medium was then removed and the cells were incubated with medium unamended (control) or amended with varied concentrations of test samples. After another $24 \mathrm{~h}$ of incubation, the medium was removed and replaced with medium containing $50 \mu \mathrm{g} / \mathrm{mL}$ NR. The NR-containing medium had been preincubated overnight at $37^{\circ} \mathrm{C}$ and was centrifuged prior to use to remove fine precipitates of dye crystals. The microtiter plate was returned to the incubator for an additional $3 \mathrm{~h}$ to allow for the uptake of the dye into the lysosomes of viable, uninjured cells. Thereafter, the medium was removed and the cells were quickly washed with $0.2 \mathrm{~mL}$ of a fixative $\left(1 \%\right.$ formaldehyde- $\left.1 \% \mathrm{CaCl}_{2}\right)$ and then $0.2 \mathrm{~mL}$ of a solution of $1 \%$ acetic acid-50\% ethanol was added to each well to extract the dye. After an additional $10 \mathrm{~min}$ at room temperature and rapid agitation on a microtiter plate shaker, the plate was transferred to a microplate reader (TECAN GENios A-5002, Austria) equipped with a 535-nm filter to measure absorbance of the extracted dye.

\section{EROD Assay}

The EROD assay was performed according to the method described by Donato et al. (1992) and Wang et al. (2003). H4IIE rat hepatoma cells were grown in Dulbecco's minimum essential medium supplemented with $10 \%$ fetal calf serum. The cells were incubated at $37^{\circ} \mathrm{C}$, in a humidified $5 \% \mathrm{CO}_{2}$ incubator. For the EROD assay, cells were seeded at a density of $2 \times 10^{4} /$ well in a 96-well plate. The cells were exposed for $72 \mathrm{~h}$ to medium containing different doses of 2,3,7,8tetrachlorodibenzo-p-dioxin (TCDD) standards (Cambridge Isotope Laboratories, Inc.), dimethyl sulphoxide (DMSO solvent control, Sigma, St. Louis, MO), or the test samples. Thereafter, the medium was removed and $100 \mu \mathrm{L}$ of fresh medium containing $8 \mathrm{mM}$ 7-ethoxyresorufin (Sigma) and $10 \mathrm{mM}$ dicumarol (Sigma) was added for an additional $60 \mathrm{~min}$ of incubation at $37^{\circ} \mathrm{C}$. Next, the medium was transferred to a new 96-well plate and mixed with $130 \mu \mathrm{L}$ of absolute ethanol. Resorufin-associated fluorescence was measured with the excitation/emission wavelength of 535/595 nm (TECAN GENios A5002, Austria). Thereafter, the total protein content was measured as described by Bradford (1976). Data obtained from EROD assays were normalized to total cellular protein. The biological TCDD-EQ values were calculated according to Hanberg et al. (1991) comparing the inducting of enzyme activity by environmental sample extracts with the series concentration of TCDD standard. The dose-response curves (Poch et al. 1995) for the induction of EROD activity were constructed by software ALLFIT. Dioxin-like potentials detected in the samples were standardized against 2,3,7,8-TCDD and expressed as TCDD equivalents (TCDD-EQ) in $\mathrm{pg}$ TCDD/L

\section{Yeast Assay}

Recombinant yeast (Saccharomyces cerevisiae) cells were kindly provided by J.P. Sumpter from Brunel University, Uxbridge, UK. The yeast assay was carried out as described by Routledge and Sumpter (1996) and Wu et al. (2002) with some modifications.

Selective medium (SC medium) was prepared following the procedures of Gaido et al. (1997) and Routledge and Sumpter (1996). All chemicals have a purity of $>99.9$ and none was re-purified prior to use. The yeast strain was grown at $30^{\circ} \mathrm{C}, 130 \mathrm{rpm}$ overnight, in Erlenmeyer flasks using $\mathrm{CuSO}_{4}$ supplemented $\left(5 \times 10^{-8} \mathrm{M}\right) \mathrm{SC}$ medium. In performing the assay, exponentially growing overnight cultures were diluted with $\mathrm{SC}$ medium to an $\mathrm{OD}_{600 \mathrm{~nm}}$ of 0.25 .

All the samples were determined in a minimum of triplicates. Each triplicate included a positive control (17 $\beta$-estrodiol) and a negative control (DMSO). The effects of estrogenic compounds were standardized against $17-\beta$-estradiol $\left(\mathrm{E}_{2}\right)$. Each test extract was diluted in a 1:2 series in DMSO for a total of 6 concentrations. Five microliters of serial dilutions of test samples were combined with $995 \mu \mathrm{L}$ of medium containing $5 \times 10^{3}$ yeast cells $/ \mathrm{mL}$ resulting in a test culture in which the volume of DMSO did not exceed $0.5 \%$ of the total volume. Two hundred microliters of the test cultures were transferred into each well of the 96-well plate and incubated at $30^{\circ} \mathrm{C}$ with vigorous orbital shaking $(130 \mathrm{rpm})$ on a titer plate shaker (Heidolph TITRAMAX 1000, Germany) for $2 \mathrm{~h}$, then the cell density of the culture was measured at 600 -nm wavelength (TECAN GENios A5002, Austria).

A $50-\mu \mathrm{L}$ test culture was transferred to a new 96-well plate and after addition of $120 \mu \mathrm{L}$ of Z-buffer and $20 \mu \mathrm{L}$ chloroform, the assays were carefully mixed (vortex $25 \mathrm{~s}$ ) and preincubated for $5 \mathrm{~min}$ at $30^{\circ} \mathrm{C}$. The enzyme reaction was started by adding $40 \mu \mathrm{L}$ o-NPG (13.3 mM, dissolved in Z-buffer). The assays were incubated at $30^{\circ} \mathrm{C}$ on a titer plate shaker. The reactions were terminated by the addition of $100 \mu \mathrm{L} \mathrm{Na} \mathrm{CO}_{3}(1 \mathrm{M})$. For E2, the incubated time lasted for 20 min and for the samples it lasted for $60 \mathrm{~min}$. After centrifugation at $12,000 \mathrm{~g}$ for $15 \mathrm{~min}$ (Sigma Laborzentrifugen 2K15, Germany), $200 \mu \mathrm{L}$ of the supernatant was transferred into a new 96-well plate and the $\mathrm{OD}_{420 \mathrm{~nm}}$ was determined. The $\beta$-galactosidase activity was calculated according to the following equations: $u=C_{S} / t \cdot V \cdot D \cdot O D_{S}$ and $C_{S}=10^{-6}\left(A_{S}-A_{B}\right) / \varepsilon \cdot d$ where $u: \beta-$ galactosidase activity; $t$ : incubation duration of the enzyme reaction; $V$ : Volume of the test culture; $D$ : dilution factor; $O D_{S}: \mathrm{OD}_{600}$ of test culture; $A_{S}: \mathrm{OD}_{420}$ of the enzyme reaction supernatant of the sample; $A_{B}: \mathrm{OD}_{420}$ of the enzyme reaction supernatant of the blank; $\varepsilon: \varepsilon$ for $o$-nitrophenol in the enzyme assay reaction mix; and $d$ : diameter of the cuvette (Routledge and Sumpter, 1996; Gaido et al. 1997). The estradiol equivalents (EEQ) values were calculated as described by $\mathrm{Wu}$ et al. (2002), comparing the estrogenic activity of the sample extracts with the series concentrations of E2 standard.

In all the bioassays, the procedural blank, which had been subjected to SPE and fractionation, was also run alongside the samples to monitor for a false-positive result.

\section{Results and Discussion}

\section{Cytotoxic Chemicals}

Acute toxicities of the three fractions in the organic extracts from the effluents treated by different treatment processes were evaluated by using an NR assay. According to our fractionation protocol, F1 extract was mainly composed of chemicals such as polychlorinated biphenyls (PCBs) and alkylhydrocarbon. Chemicals such as polycyclic aromatic hydrocarbons (PAHs), organic chlorinated pesticides (OCPs), polychlorinated dibenzofurans (PCDFs), and dibenzo- $p$-dioxins (PCDDs) would be contained in F2. F3 was mainly composed of organic components such as substitution benzene, phenol, 


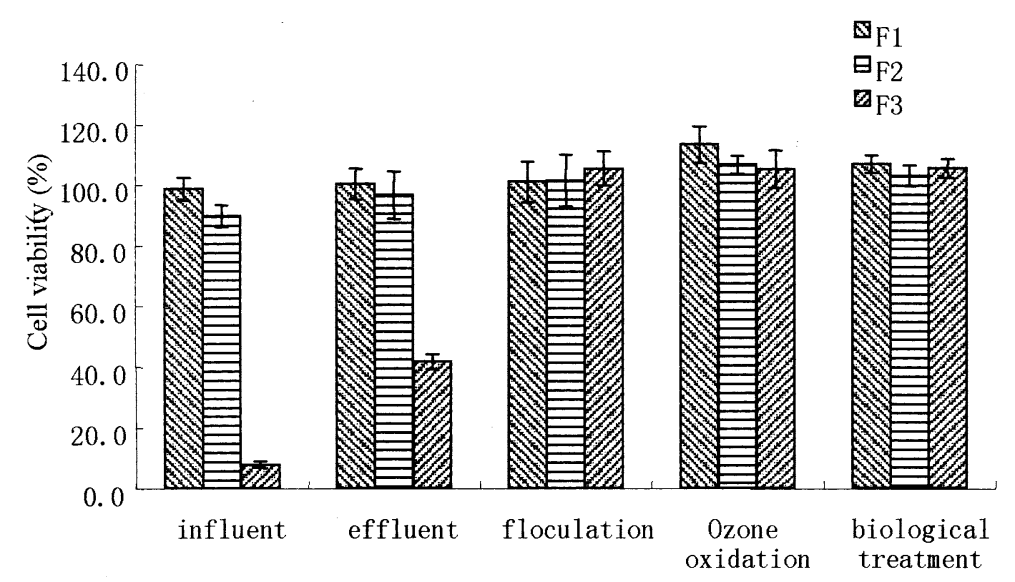

Fig. 2. Cytotoxicity in the fractionated samples by NR assay and organic acid (Wang et al. 2001a; Chul-Hwan Koh et al. 2002.). The results (Fig. 2) showed that the cytotoxicity was mainly contributed by the chemicals in F3. Chemicals in the other two fractions showed no obvious acute toxic effects. Among different samples, chemicals in the influent (A) induced a strong cytotoxicity response in which the cell viability was no more than $10 \%$. In the effluent from secondary treatment (B), the cell viability rose up to more than $40 \%$, indicating the biodegradability of some polar chemicals. The flocculation (C) removed the cytotoxicity completely and there were no toxic manifestations in effluents from the following treatments, including ozone oxidation and post-biological treatment.

Several of cytotoxicity assays have been employed for the evaluation of environment pollutants (Fent and Hunn 1996, Putnam et al. 2002). They have a different mechanistic basis, and thus may give some hints as to the biochemical mechanism of toxic action. The NR assay, which is one of the most commonly used cytotoxicity assays, is based on the accumulation of Neutral Red in lysosomes of viable cells (Borenfreund and Puerner 1985). Compounds causing membrane damage inhibit the accumulation of this dye, and cells lose their red color. The NR assay has been widely used in the evaluation of environmental pollutants (Babich and Borenfreund 1987b; Fent 1996) and environmental samples (Dayeha et al. 2002). Many compounds, including methyl mercury, chlorophenols, nitrotoluenes, chlorotoluenes, nitrophenols, methylphenols, phenols, toluenes, nonylphenol, and octylphenol, etc., have been found to be cytotoxic in the NR assay (Babich and Borenfreund 1987b). The rank order of cytotoxicity of these compounds depends on the position and the number of the substitute groups, which display different modes of toxic action. For example, the higher substituted chloro- and nitrophenols are uncouplers of oxidative phosphorylation, whereas lower substituted phenols act via narcotic-type mechanisms, 4-nonylphenol and 4-octylphenol, which primarily act on cell membranes at high concentrations and bind to the estrogen receptor at low concentrations (Fent 1996). Organotin compounds act both as inhibitors of oxidative phosphorylation and as membrane toxicants (Fent, 1996). The cytotoxicity of all these pollutants with different action modes could be clearly detected by NR assay and was found to have a good correlation with their in vivo waterborne acute toxicity (Babich and Borenfreund 1987b; Fent 1996). Numerous cell viability measurements by NR assay after exposure to industrial and municipal wastewaters (Gagné and Blaise 1998) showed that comparison of data from the NR assay with those for toxic potential to rainbow trout reveal a significant relationship ( $\mathrm{r}=0.975, p<0.001)$. In our study, it was found that the cytotoxicity was dominantly produced in a polar fraction, which usually has low lipophilicity. However, positive correlation between cytotoxicity and lipophilicity of substituted phenolics and chlorinated toluenes in the NR assay was found in some other studies (Babich and Borenfreund 1987b, Fent 1996). Our observation could be explained by the complexity of the environmental samples, in which thousands of pollutants with different properties are included. The integrate effects could not be predicted and explained simply by the lipophilicity as for a single compound. Therefore, in this study, in combination with sample fractionation, the NR assay could reflect the fact that most of cytotoxic chemicals in the investigated wastewater were of high polarity, and some of them could be removed by the secondary treatment and most of them by flocculation.

\section{Dioxin-Like Chemicals}

The dioxin-like chemicals were detected in all three fractions (Fig. 3). The results showed that the total TCDD-EQ of dioxin-like chemicals in the influent and the effluents was lower than $14 \mathrm{pg}$ TCDD/L. This value was even far below the Drinking Water Maximum Contaminant Level (MCL value) (30 pg TCDD /L), recommended by the US EPA (2002b). The variations of TCDD-EQ in different fractions and/or in different treatment processes could be observed clearly by this biomarker. In the influent, the highest effect was produced by F3 extracts, while F1 contributed less than F2, the least to the total effects. After the secondary treatment, effects elicited by F2 and F3 extracts were raised up slightly, whereas the F1produced effect decreased. This result suggested that some non-polar chemicals were transformed into polar and moderate polar intermediate during the secondary treatment process. It was also possible that some non-polar chemicals were eliminated by precipitation during this treatment process. Flocculation eliminated 97\% F3-produced effect and 48\% F2produced effect, indicating the high efficiency of flocculation to remove polar and moderate-polar dioxin-like chemicals. 

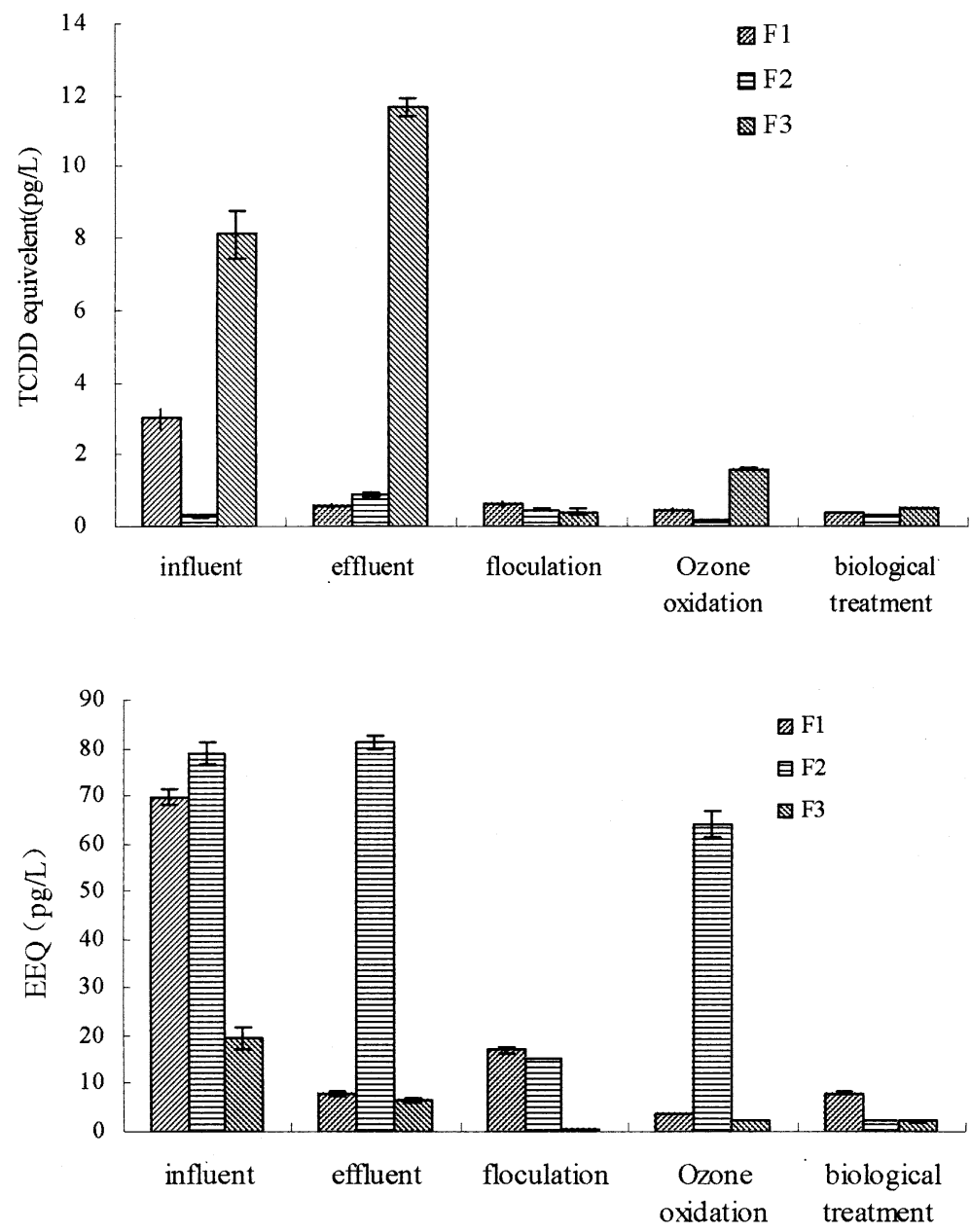

Fig. 3. Dioxin-like effects in the fractionated samples by EROD assay
The F3-produced effect became higher after ozone oxidation, suggesting the formation of more polar dioxin-like chemicals, which are easier to degrade in the post-biological treatment process.

It is well known that dioxin-like chemicals include dioxins, furans, polychlorinated naphthalenes (PCNs), polychlorinated biphenyls (PCBs), and polycyclic aromatic hydrocarbons (PAHs), which are ubiquitous contaminants in environmental matrices, including biota, sediment, air, surface waters, and municipal and industrial effluents (Dorr et al. 1996; Falandysz et al. 1996; Harner and Bidleman, 1997; Kannan et al. 1998; Villeneuve et al. 2000). Most of these compounds are of low polarity and, therefore, are not expected to be in the polar fraction (F3). The unexpected levels of F3 dioxin-like activity possibly suggested unidentified, relatively polar, AhR agonists (Khim et al. 1999a,b, Brack et al. 2003). Another possible explanation of our observations is that the test was performed for water only and most of the hydrophobic chemical should be concentrated in the sludge or suspended matter, which was removed from the sedimentation processes. Also, dioxin-like chemicals are found in the environment as complex mixtures of both AhR-active and AhR-inactive congeners, and interactions between active and inactive congeners may complicate the effects on in vitro bioassay responses (Sanderson et al. 1996). It was illustrated that the EROD assay may underestimate the potential toxicity of chemicals, such as PAHs and other AhR ligands that are readily metabolized (Bols et al.1997; Whyte et al. 2004). Large molecular weight hydrophobic PAHs can be AhR active, but they are easily metabolized or transformed in part due to their lack of halogenations (Nebert et al., 2000). Some of the polar chemicals, such as nitro-aromatic hydrocarbons, could also induce dioxin-like effects in EROD assay (Wang et al. 2001b). After treated by the flocculation, dioxin-like chemicals were largely removed and levels in effluents of ozone oxidation and post biological treatment were 2-3 pg TCDD-TEQ/L. Therefore, it could be concluded that dioxin-like chemicals in the soluble phase of wastewaters should be, at least in this case study, negligible and control of this type of chemicals could be done by efficient precipitation.

\section{Estrogenic Chemicals}

In the influent, the $17 \beta$-estradiol equivalent (EEQ) of estrogenic chemicals was $163.4 \mathrm{pg}$ EEQ /L (Fig. 4). The value is much lower than those of some WWTPs effluents in other countries (Cargouët et al. 2003; Pawlowski et al. 2004; Svenson et al. 2003). It can be seen that most of the estrogenic chemicals in the influent were non-polar or moderate polar. Sewage effluent has been shown to contain synthetic chemicals including nonylphenols, phthalic esters, PCBs, dioxins, 
and phytoestrogens as well as synthetic estrogens from a contraceptive pill that are able to disrupt the endocrine system (Fawell et al. 2001; Belfroid et al. 1999). Desbrow et al. (1998) revealed that estrogenic activity in some rivers in the United Kingdom is caused by the presence of $17 \beta$-estradiol and estrone, as well as the synthetic birth control contraceptive $17 \alpha$-ethinylestradiol. 17 $\beta$-estradiol, estrone, and $17 \alpha$-ethinylestradiol had been detected in effluents of WWTPs in Britain, Israel, and Germany. Most of these compounds are inactive after metabolizing in the body. However, microorganisms may hydrolyze sulfate and glucuronide conjugate of excreted estrogenic steroids in treated effluents, and most probably also in sewage prior to treatment (Baronti et al. 2000). Although these conjugates are not active estrogens, hydrolysis transforms them into active products that may exert their effect. The F-1 and F-3 produced effects could be eliminated to a very low level by the secondary biological treatment process, while the F-2 produced effect remained at the same level after this treatment process.

The flocculation process could eliminate more than $75 \%$ of the F-2 produced effect and the total effect produced by F-3. This is quite similar to the high removal efficiency of polar and moderate-polar dioxin-like chemicals in the flocculation treatment we observed in the EROD assay. However, the effect of F-1 was slightly greater after flocculation. This is also in accordance with the result we obtained in the EROD assay. In our previous study (Ma et al. 2001), we found in the Ames test that flocculation treatment could induce mutagenicity, which is most probably caused by chemicals with low polarity (Wang and Liu 1999). All of these results proved the fact that some non-polar chemicals with low molecular weight may be released from the large-molecule organic substances, such as humic substances, during flocculation treatment, thereby exerting toxic effects (Wang and Liu 1999).

Although ozone oxidation could remove the F1-produced estrogenic effect to a very low level, the F2-produced effect increased greatly. The increase of polarity of estrogenic chemicals by ozone oxidation might be due to the induced oxygen; thus, many chemicals are transformed into more biodegradable species in this process (Ling and Zhang 2002). Ozone oxidation followed by the biological treatment could completely eliminate the F2-produced effects, and in the final effluent $92 \%$ of effects were eliminated. Therefore, the combination of flocculation, ozone oxidation, and microbiological treatment is the most efficient way to eliminate the estrogenic effects in the influent of Gaobeidian WWTP.

Many studies have been performed on the removal of estrogenic chemicals in the sewage treatment processes. High rates of removal of natural and synthetic estrogens in biological sewage treatment plants were found in Brazil and Germany (Ternes et al. 1999). Sewage treatment processes in Italy could remove $61-95 \%$ of E1, E2, and EE2. However, some estrogenic chemicals could not be eliminated by the secondary treatment. It was reported that certain natural and synthetic hormones and alkyl-phenolic surfactants could not be removed during the biological treatment process and their estrogenic effects were even increased or activated (Nasu et al. 2001). In comparison, we can conclude that the removal efficiency of estrogenic chemicals from secondary treatment process depends on the chemical characteristics of the sewage. In our case, the mixture of both domestic and industrial wastewater in the influent to the WWTP complicates the situation and the integrative treatment system is efficient for removal of these chemicals.

\section{Conclusions}

By using a battery of bioassays, levels of cytotoxic, dioxinlike, and estrogenic chemicals in influent of WWTP and effluents of different treatment processes could be evaluated. The combination of fractionation and bioassays based on biomarkers is especially useful to identify the properties of these chemicals and elucidate the mechanism of each treatment process for each category of chemical. The proposed procedure could be used to assess the technique feasibility when reclamations of the wastewater are of ecological and health concerns. For example, it could be used in the screening stage (Tier 1) of WET and be used as a tool of diagnosis in the toxic identification and evaluation procedure (TIEs).

The secondary treatment in WWTP is efficient to remove the acute toxic chemicals as well as non-polar dioxin-like and estrogenic chemicals. The flocculation, as an advanced treatment technology, could eliminate most of the polar and nonpolar dioxin-like and estrogenic chemicals. More polar or moderate polar dioxin-like and estrogenic chemicals were formed by ozone oxidation. However, it leads to the chemicals becoming more biodegradable and thus much easier to remove by following the biological treatment.

Acknowledgments. The authors appreciated the assistance of colleagues from Beijing WWTP, especially Dr. Jun Zhou for sampling. This study was supported by the National Natural Science Foundation of China (20337020) and National Basic Research Program of China (2003CB415005).

\section{References}

Alatriste-Mondragon F, Iranpour R, Ahring BK (2003) Toxicity of di(2-ethylhexyl)phthalate on the anaerobic digestion of wastewater sludge. Water Res 37:1260-1269

Babich H, Borenfreund E (1987a) Fathead minnow FHM cells for use in in vitro cytotoxicity assays of aquatic pollutants. Ecotoxicol Environ Safe 14:78-87

Babich H, Borenfreund E (1987b) In vitro cytotoxicity of organic pollutants to Bluegill Sunfish (BF-2) cell. Environ Res 42:229 237

Baronti C, Curini R, D'Ascenzo G, Di Corcia A., Gentili Samperi A R (2000) Monitoring natural and synthetic estrogens at activated sludge sewage treatment plants and in a receiving river water. Environ Sci Technol 34:5059-5066

Belfroid AC, Van der Horst A, Vethaak AD, Schäfer AJ, Rijs GBJ, Wegener J, Cofino WP (1999) Analysis and occurrence of estrogenic hormones and their glucuronides in surface water and waste water in the Netherlands. Sci Total Environ 225:101-108

Betowski LD, Kendall DS, Pace CM, Donnelly JR (1996) Characterization of groundwater samples from superfund sites by gas chromatography/mass spectrometry and liquid chromatography/ mass spectrometry. Environ Sci Technol 30:3558-3564

Bols NC, Whyte JJ, Clemons JH, Tom DJ, van den Heuvel MR, Dixon DG (1997) Use of liver cell lines to develop TCDD equivalency factors and TCDD equivalent concentrations in environmental 
samples. In: Zelikoff JT, (eds) Ecotoxicology: responses, biomarkers and risk assessment. SOS Publishing, Fair Haven, NJ, pp 329

Borenfreund E, Puerner JA (1985) Toxicity determined in vitro by morphological alterations and neutral red absorption. Toxicol Lett 24:119-124

Brack W, Kind T, Schrader S, Möder M (2003) Sequential fractionation procedure for the identification of potentially cytochrome P450 1A-inducing compounds. J Chrom A 986:55-66

Bradford MM (1976) A rapid and sensitive method for the quantitation of microgram quantities of protein utilizing the principle of protein-dye binding. Anal Biochem 72:248-254

Cargouët M, Perdiz D, Mouatassim-Souali A, Tamisier-Karolak S, Levi Y (2004) Assessment of river contamination by estrogenic compounds in Paris area (France). Sci Total Environ 324:5-66

Chul-Hwan Koh, and Jong Seong Khim, Daniel Villeneuve L, Kurunthachalam Kannan, John P. Giesy (2002) Analysis of trace organic contaminants in sediments in sediment, pore water, and water samples from Onsan bay, Korea: instrumental analysis and in vitro gene expression assay. Environ Toxicol Chem 21:17961803

Clara M., Kreuzinger N., Strenn B (2005) The solids retention time: a suitable design parameter to evaluate the capacity of wastewater treatment plants to remove micropollutants. Water Res 39:97-106

Dayeha VR, Schirmerb K, Bolsa NC (2002) Applying whole-water samples directly to fish cell cultures in order to evaluate the toxicity of industrial effluent. Water Res 36:3727-3738

Desbrow C, Routledge E, Brighty GC, Sumpter J, Waldock M (1998) Identification of estrogenic chemicals in STW effluent. 1. Chemical fractionation and in vitro biological screening. Environ Sci Technol 32:1549-1558

Donato MT, Castell JV, Gómez-Lechón J (1992) A rapid and sensitive method for measuring monooxygenase activities in hepatocytes cultured in 96-well olates. J Tissue Culture Methods 14:153-158

Dorr G, Hippelein M, Hutzinger O (1996) Baseline contamination assessment for a new resource recovery facility in Germany. Part V: analysis and seasonal/regional variability of ambient air concentrations of polychlorinated naphthalenes (PCNs). Chemosphere 33:1563-1568

Falandysz J, Strandberg L, Bergqvist PA, Kulp SE, Strandberg B, Rappe C (1996) Polychlorinated naphthalenes in sediments and biota from the Gdansk Basin Baltic Sea. Environ Sci Technol 30:3266-3274

Fawell JK, Sheahan D, James HA, Hurst M, Scott S (2001) Oestrogens and Oestrogenic activity in raw and treated water in severn trent water. Water Res 35:1240-1244

Fent (1996) Ecotoxicology of organotin compounds. CRC Crit Rev Toxicol 26:1-117

Fent K, Hunn J (1996) Cytotoxicity of organic environmental chemicals to fish liver cell (PLHC-1). Marine Environ Res 42:377-382

Gagné F, Blaise C (1998) Differences in the measurement of cytotoxicity of complex mixtures with rainbow trout hepatocytes and fibroblasts. Chemosphere 37:753-769

Gaido KW, Leonard LS, Lovell S, Gould JC, Babaï D, Portier CJ, McDonnell DP (1997) Evaluation of chemicals with endocrine modulating activity in a yeast-based steroid hormone receptor gene transcription assay. Toxicol Appl Pharmacol 143:205-212

Giesy JP, Hilscherova K, Jones PD, Kannan K, Machala M (2002) Cell bioassays for detection of aryl hydrocarbon (AhR) and estrogen receptor (ER) mediated activity in environmental samples. Marine Pollut Bull 45:3-16

Go V, Garey J, Wolff MS, Pogo BGT (1999) Estrogenic potential of certain pyrethroid compounds in the MCF-7 human breast carcinoma cell line. Environ Health Perspect 107:173-177

Hanberg M, Strahlberg A, Georgellis A (1991) Swedish Dioxin survey envalution of the $\mathrm{H}_{4}$ IIE bioassay for screening environmental samples for dioxin-like enzyme induction. Pharmacol Toxicol 69:442-449

Hankinson O (1995) The aryl hydrocarbon receptor complex. Annu Rev Pharmacol Toxicol 35:307-340

Hansen PD, Addisson RF (1990) The use of mixed function oxidase to support biological effects monitoring the sea. Marine Environmental Quality Committee Int Council Explor Sea E:333

Harner T, Bidleman TF (1997) Polychlorinated naphthalenes in urban air. Atmos Environ 31:4009-4016

Hilscherova K, Kannan K, Kang YS, Holoubek I, Machala M, Masunaga S, Nakanishi J, Giesy JP (2001) Characterization of dioxin-like activity of sediments from a Czech river basin. Environ Toxicol Chem 20:2768-2777

Kannan K, Imagawa T, Blankenship A, Giesy JP (1998) Isomer specific analysis and toxic evaluation of polychlorinated naphthalenes in soil, sediment, and biota near the site of a former chlor-alkali plant. Environ Sci Technol 32:2507-2514

Khim JS, Villeneuve DL, Kannan K, Koh CH, Giesy JP (1999a) Characterization and distribution of trace organic contaminants in sediment from Masan Bay, Korea: 2. In vitro gene expression assays. Environ Sci Technol 33:4206-4211

Khim JS, Villeneuve DL, Kannan K, Koh CH, Giesy JP (1999b) Characterization and distribution of trace organic contaminants in sediment from Masan Bay, Korea: 1. Instrumental analysis. Environ Sci Technol 33:4199-4205

Knörr S, Braunbeck T (2002) Decline in reproductive success, sex reversal, and developmental alterations in Japanese Medaka (Oryzias latipes) after continuous exposure to octylphenol. Ecotoxicol Environ Safe 51:187-196

Ling B, Zhang XJ (2002) Hygiene and treatment technology of drinking water. Chemical Industry Press, Beijing, p 344

Lucier GW, Portier CJ, Gallo MA (1993) Receptor mechanism and dose-response models for the effects of dioxins. Environ Health Perspect 1:36-44

Ma M, Wang ZJ, Shang W, Wang CX, Wang WH (2000) Mutagenicity and acute toxicity of waters from different treatment processes in Beijing waterworks. J Environ Sci Health 35:88-96

Murk AJ, Legler J, Van Lipzig MMH, Meerman JHN, Belfroid AC, Spenkelink A, Van der Burg B, Rijs GBJ, Vethaak D (2002) Detection of estrogenic potency in wastewater and surface water with three in vitro bioassays. Environ Toxicol Chem 21:16-23

Nasu M, Goto M, Kato H, Oshima Y, Tanaka H (2001) Study on endocrine disrupting chemicals in wastewater treatment plants. Water Sci Technol 43:101-108

Nebert DW, Roe AL, Dieter MZ, Solis WA, Yang Y, Dalton TP (2000) Role of the aromatic hydrocarbon receptor and Ah gene battery in the oxidative stress response, cell cycle control, and apoptosis. Biochem Pharmacol 59:65-85

Pawlowski S, Ternes TA., Bonerz M, Rastall AC, Erdinger L, Braunbeck T (2004) Estrogenicity of solid phase-extracted water samples from two municipal sewage treatment plant effluents and river Rhine water using the yeast estrogen screen. Toxicol In Vitro 18:129-138

Poch G, Reiffenstein RJ, Kock P, Pancheva SN (1995) Uniform characterization of potentiation in simple and complex situations when agents bind to different molecular sites. Can J Physical Pharmacol 73:1574-1581

Putnam KP, Bombick DW, Doolittle DJ (2002) Evaluation of eight in vitro assays for assessing the cytotoxicity of cigarette smoke condensate. Toxicology in Vitro 16:599-607

Ramamoorthy K, Wang F, Chen IC, Norris JD, McDonnell DP, Leonard LS, Gaido KW, Bocchinfuso WP, Korach KS, Safe S (1997) Estrogenic activity of a dieldrin/toxaphene mixture in the mouse uterus, MCF-7 human breast cancer cells, and yeast-based estrogen receptor assays: no apparent synergism. Endocrinology 138:1520-1527 
Rao KF, Ma M, Wang ZJ, Liu LJ (2005) The variation of estrogenic effects during water treatment processes in a drinking water works in South China. Environ Sci (in press)

Routledge EJ, Sumpter JP (1996) Estrogenic activity of surfactants and some of their degradation products assessed using a recombinant yeast screen. Environ Toxicol Chem 15:241-248

Sanderson JT, Aarts JMMJG, Brouwer A, Froese KL, Denison MS, Giesy JP (1996) Comparison of Ah receptor-mediated luciferase and ethoxyresorufin-Odeethylase induction in H4IIE cells: implications for their use as bioanalytical tools for the detection of polyhalogenated aromatic hydrocarbons. Toxicol Appl Pharmacol 137:316-325

Sohoni P, Soto JP (1998) Several environmental oestrogens are also antiandrogens. J Endocrinol 158:327-339

Svenson A, Allard AS, Ek M (2003) Removal of estrogenicity in Swedish municipal sewage treatment plants. Water Res 37:44334443

Tabata A, Kashiwada S, Ohnishi Y, Ishikawa H, Miyamoto N, Itoh M, Magara Y (2001) Estrogenic influences of estrodiol-17b, pnonyphenol and bis-phenol-A on Japanese Medaka (Oryzias latipes) at detected environmental concentrations. Water Sci Technol 43:109-116

Ternes TA, Stumpf M, Mueller J, Haberer K, Wilken R-D, Servos M (1999) Behavior and occurrence of estrogens in municipal sewage treatment plants-I investigations in Germany, Canada and Brazil. Sci Total Environ 225:81-90

Toppari J, Larsen JC, Christiansen P, Giwercman A, Grandjean P, Guillette LJ Jr, Je gou B, Jensen TK, Jounnet P, Keiding N, Leers H, McLachlan JA, Heyer O, Muller J, Rajpert-De Meyts E, Scheike T, Sharpe R, Sumpter JP, Skakkebaek NE (1996) Male reproductive health and environmental xenooestrogens. Environ Health Perspect 104:741-776

US EPA (2002a) Short-term method for estimating the chronic toxicity of effluents and receiving waters to freshwater organisms. Fourth Edition, October. Office of Water, U.S. Environmental Protection Agency Washington, DC
US EPA (2002b) 2002 Edition of the drinking water standards and health advisories, EPA 822-R-02-038, Office of Water, U.S. Environmental Protection Agency Washington, DC

Villeneuve DL, Khim JS, Kannan K, Falandysz J, Blankenship AL, Giesy JP (2000a) Relative potencies of individual polychorinated naphthalenes to induce dioxin-like responses in fish and mammalian in vitro bioassays. Arch Environ Contam Toxicol 39:273-281

Wang C, Wang Y, Kiefer F, Yedeler A, Wang Z, Kettrup A (2003) Ecotoxicological and chemical characterization of selected treatment process effluents of municipal sewage treatment plant. Ecotoxicol Environ Saf 56:211-217

Wang Y, Wang ZJ, Ma M, Wang CX, Mo Z (2001a) Monitoring priority pollutants in a sewage treatment process by dichloromethane extraction and triolein-semipermeable membrane device (SPMD). Chemosphere 43:339-346

Wang Y, Wang CX, Wang ZJ, Xu JB (2001b) EROD induction in liver microsome of Carp (Cyprinus Carpio) by nitroaromatic hydrocarbons in vitro. Environ Sci 22:111-113

Wang ZS, Liu WJ (1999) Drinking water treatment technology for micro-pollutants- contaminated source water. China architecture and building press, Beijing, 172

Whyte JJ, Schmitt CJ, Tillitt DE (2004) The H4IIE cell bioassay as an indictor of dioxin-like chemicals in wildlife and the environment. Crit Rev Toxicol 34:1-83

Wu WZ, Schwirzer SMG, Schramm KW et al. (1996) Rapid bioassay as indicator of potential harmful effects for dioxin-like compounds in sample of Ya-er lake, analysis. Fresenius Environ Bull 5:374-379

Wu WZ, Wang JX, Zhao GF, You L (2002) The emission soot of biomass fuels combustion as a source of endocrine disrupters. J Environ Sci Health A 37:579-600

Zacharewski TR, Berhane K, Gilllesby BE, Burnison BK (1995) Detection of estrogen-and dioxin-like activity in pulp and paper mill black liquor and effluent using in vitro recombinant receptor/ reporter gene assay. Environ Sci Technol 29:2140-2146 